\title{
A Note on Using UCA Cash Flow Analysis to Discern the Purpose(s) of a Firm's Short-Term Debt
}

\author{
Ernest S. Fletcher, Jr. \\ Baylor University \\ John T. Rose \\ Baylor University
}

This note uses the Uniform Credit Analysis (UCA) Cash Flow Statement to explore the purpose(s) of a firm's short-term debt. Employing a fictional firm, we examine whether the firm's short-term borrowing is entirely intended to fund the firm's net current assets. The results suggest a financing mismatch in the firm's use of short-term debt in all three years of the study period, either to help fund the firm's investment in capital (long-term) assets or to cover the firm's current portion of long-term debt. This analysis provides a useful technique for lending institutions to discern whether potential or existing commercial customers are using short-term debt for a purpose(s) other than supporting net current assets.

\section{INTRODUCTION}

Recent research by Beach et al. (2017) compares the FASB 95 and Uniform Credit Analysis (UCA) cash flow statements and discusses the benefits of the UCA format. Noting that the FASB 95 statement is static in nature whereas the UCA statement is more dynamic in focus, the authors argue that the UCA format is a superior tool for commercial credit analysis.

One issue on which the UCA statement of cash flows can offer additional insight relates to the purpose(s) of a firm's short-term debt. Specifically, is the firm's short-term debt solely intended to fund the firm's net current assets? Or is the firm increasing its risk profile by using short-term borrowing to pay the current portion of long-term debt and/or to fund, at least in part, capital (long term) assets? These questions are important to creditors for determining the purpose of any loan request or advances on an existing Revolving Line of Credit (RLOC), as well as to investors when assessing a firm's risk exposure.

In this regard, it is worth noting that a basic commercial loan underwriting principle is to match the term of a loan with the life and cash flow of the pledged asset. This lending technique (sometimes known as short-to-short and long-to-long) is crucial for the sustained health of a growing company. Short-Term Notes Payable on a firm's balance sheet are typically advances against a RLOC to support net current assets. Such advances are commonly secured by eligible accounts receivable and inventory and based on a firm's unused borrowing capacity. A company can potentially experience liquidity problems and increase the probability of financial distress if it uses the borrowing capacity under its short-term RLOC 
to make a payment on the current portion of a long-term debt obligation and/or to purchase a long-term asset(s).

To analyze the intent of a firm's short-term borrowing using information in the UCA Cash Flow Statement we draw in the next section on the financial statements of a fictional firm, Pittman Plumbing Fixtures \& Supplies, Inc. (Pittman), for the years 2015-18. Pittman is a regional, closely-held C Corporation that wholesales plumbing fixtures and supplies. The attached financial statements of Pittman include Table 1, year-end balance sheets; Table 2, annual income statements; and Table 3, annual UCA cash flow statements. To add further clarity to the question of Pittman's use of short-term debt during the study period, we present in the third section an alternative method for examining the intent of Pittman's short-term borrowing by rearranging the presentation of the firm's UCA cash disbursements following Cash After Financing Costs, as shown in Table 4. The last section is a summary and conclusion.

\section{DISCERNING THE PURPOSE(S) OF PITTMAN'S SHORT-TERM DEBT}

Presented with Pittman's UCA cash flow statements for the years 2016-18, we can discern the purpose(s) of any increase in short-term debt by focusing on the cash flows following Cash After Financing Costs on the UCA cash flow statements. As shown in Table 3, Cash After Financing Costs is followed by disbursements for the Current Portion of Long-Term Debt (CPLTD) and Plant \& Investments, plus any inflows/outflows owing to Related Parties-Change in Loans from Owners. The result is a Financing Surplus (Requirement), followed by External Financing in the form of changes in Short-Term Debt, Long-Term Debt, Contributed Capital, Other Changes in Retained Earnings, and finally any Change in Cash \& Equivalents.

Looking first at 2016, Cash After Financing Costs was $\$ 18,874$, which was enough to cover the CPLTD of $-\$ 17,889$, leaving Cash After Debt Amortization of $\$ 985$. This amount helped to cover Plant \& Investments of $-\$ 6,527$ but was short by $-\$ 5,542$. To meet this deficit Pittman raised external funding in the amounts of $\$ 3,200$ in Short-Term Debt and $\$ 1,149$ in Long-Term Debt. However, these funds were still insufficient to meet the Financing Requirement of $-\$ 5,542$, so the firm reduced its Cash \& Equivalents by $-\$ 1,193$. Most significantly though, the firm used $\$ 3,200$ of Short-Term Debt drawn against its RLOC to help cover its investment in capital (long-term) assets, thereby evidencing a financing mismatch in the use of its short-term borrowing.

Turning to 2017, Cash After Financing Costs was only \$4,468, reflecting a sharp decrease from 2016 in Cash From Trading down through Cash After Financing Costs. Moreover, this amount was insufficient

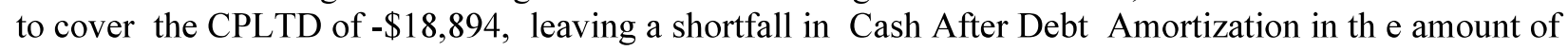
$-\$ 14,426$. Thus, with expenditures on Plant \& Investments of $-\$ 11,547$ Pittman faced a deficit of $-\$ 25,973$. To cover this deficit, the firm raised external funding in the amounts of $\$ 13,800$ in ShortTerm Debt and $\$ 12,993$ in Long-Term Debt. The $\$ 13,800$ of short-term borrowing can be viewed as covering most of the $-\$ 14,426$ shortfall in operating cash flow that was needed to cover the CPLTD, and the $\$ 12,993$ of long-term borrowing more than covered the investment in capital assets, resulting in an increase in Cash \& Equivalents of \$820. Thus, in contrast with 2016, data for 2017 suggests a near matching of long-term borrowing of $\$ 12,993$ to more than cover the firm's $-\$ 11,547$ investment in capital assets. However, like 2016 , the data also points to a financing mismatch in the use of short-term borrowing of $\$ 13,800$ to help cover the cash flow shortfall of $-\$ 14,426$ needed to pay the CPLTD since RLOCs are typically not intended to fund the CPLTD.

Finally, looking at 2018, Cash After Financing Costs increased sharply from 2017, registering $\$ 33,971$ which was more than enough to cover the CPLTD of $-\$ 19,766$, leaving Cash After Debt Amortization of $\$ 14,205$. As in 2016 , this amount helped to cover Plant \& Investments of $-\$ 37,398$ but was still short by $-\$ 23,193$. To meet this deficit, Pittman raised external funding in the amounts of $\$ 20,375$ in Short-Term Debt and $\$ 863$ in Long-Term Debt. But again, these funds were insufficient to meet the Financing Requirement of $-\$ 23,193$, so the firm reduced its Cash \& Equivalents by $-\$ 1,955$. Significantly though, as in 2016 the firm used $\$ 20,375$ of short-term borrowing drawn against its RLOC 
to help cover its expenditure for Plant \& Investments, thereby again evidencing a financing mismatch in the use of its short-term borrowing.

\section{AN ALTERNATIVE LOOK AT THE INTENT OF PITTMAN'S SHORT-TERM DEBT}

To add further clarity to Pittman's use of short-term borrowing during the study period, Table 4 gives an alternative presentation of Pittman's UCA cash disbursements following Cash After Financing Costs. Specifically, the Change in Short-Term Debt is moved up to follow Cash After Debt Amortization. The reason for this move is that if Cash After Debt Amortization is positive, thereby reflecting sufficient cash flow to cover all the operating needs of the firm plus the CPLTD, then any short-term borrowing that year must have been intended to help finance capital investments (unless the short-term borrowing was matched by an increase in Cash \& Equivalents). Hence, the Change in Short-Term Debt is followed by a new summary account, Cash Available for Plant \& Investments, which in turn is followed by Cash Used for Plant \& Investments and the remaining accounts from the UCA Cash Flow Statement. Thus, for 2016 and 2018, both of which show a positive amount of Cash After Debt Amortization, the short-term borrowing of $\$ 3,200$ in 2016 and $\$ 20,375$ in 2018 must have been intended to help fund capital investments of $-\$ 6,527$ in 2016 and $-\$ 37,398$ in 2018 , thereby evidencing a financing mismatch in the use of short-term borrowing in both years.

By contrast, if Cash After Debt Amortization is negative, then any short-term borrowing that year must have been intended, at least in part, to cover the shortfall in operating cash flow that was needed to pay the CPLTD. Thus, for 2017, which shows a negative amount of Cash After Debt Amortization, the short-term borrowing of $\$ 13,800$ must have been intended to help cover the $-\$ 14,426$ deficit in Cash After Debt Amortization, thereby evidencing another, albeit different, financing mismatch in the use of shortterm borrowing to help fund the firm's CPLTD. At the same time, the long-term borrowing of $\$ 12,993$ that year nearly matched the firm's $-\$ 11,547$ expenditure for Plant \& Investments.

\section{SUMMARY AND CONCLUSION}

Recent research dealing with the Uniform Credit Analysis (UCA) Cash Flow Statement has opened the door to enhanced cash flow analysis. One issue on which the UCA Cash Flow Statement can offer additional insight relates to the purpose(s) of a firm's short-term debt. Specifically, is the firm's shortterm debt entirely intended to fund the firm's net current assets? Or is the firm increasing its risk profile by using short-term borrowing to pay the current portion of long-term debt (CPLTD) and/or to fund, at least in part, long term (investment) assets?

This note analyzes the intent of a firm's short-term borrowing, drawing on the financial statements of a fictional firm, Pittman Plumbing Fixtures and Supplies, Inc. (Pittman) for 2015-18. Specifically, we explore the purpose(s) of the firm's short-term debt by focusing on the UCA cash flow data following Cash After Financing Costs in the UCA Cash Flow Statement for each of the years, 2016-18.

The results suggest a financing mismatch in the firm's use of short-term debt in all three years. Specifically, the data indicate Pittman used short-term borrowing in both 2016 and 2018 to help cover its investment in capital (long-term) assets. By contrast, in 2017 the firm used long-term borrowing to help finance its investment in capital assets but short-term borrowing to help cover the firm's CPLTD, another illustration of a financing mismatch in the use of its short-term borrowing.

The analysis presented here provides a useful technique for lending institutions to discern whether potential or existing commercial customers are using short-term borrowing for anything other than supporting net current assets. It also provides a springboard for expanded studies of commercial borrowing using information from the UCA Cash Flow Statement. 


\section{REFERENCES}

Beach, R., Fletcher, E. S., Jr., \& Rose, J. T. (2017). Cash Flow Statements for Commercial Credit Analysis: UCA vs. FASB 95. Advances in Financial Education, Winter, 89-107.

TABLE 1

PITTMAN PLUMBING FIXTURES \& SUPPLIES, INC.

YEAR-END BALANCE SHEETS

\section{(\$ in thousands)}

Assets

Cash \& Marketable Securities

Accounts Receivable

Reserve for Bad Debts

Inventory

Prepaid Expenses

Total Current Assets

Gross Fixed Assets

Less: Accumulated Depreciation

Net Plant and Equipment

2015

10,982

36,372

$(1,273)$

62,055

1,039

109,175

562,900

$\frac{(315,224)}{247,676}$

Other Assets

Total Assets

Liabilities

Accounts Payable

Accrued Wages/Salaries

Notes Payable - Bank

Current Maturities of Long-Term Debt

Income Taxes Payable

Total Current Liabilities

Long-Term Debt

Total Liabilities

Stockholders' Equity

Common Stock

Paid-In Capital

Retained Earnings

Total Stockholders' Equity

Total Liabilities and Stockholders' Equity
2016

2017

2018

\begin{tabular}{|c|c|c|c|}
\hline 14 & 16 & 47 & 13 \\
\hline 356,865 & 361,235 & 363,079 & 371,109 \\
\hline
\end{tabular}

\begin{tabular}{|c|c|c|c|}
\hline 33,712 & 45,607 & 37,459 & 42,557 \\
\hline 2,474 & 2,165 & 2,706 & 3,222 \\
\hline 2,000 & 5,200 & 19,000 & 39,375 \\
\hline 17,889 & 18,894 & 19,766 & 20,028 \\
\hline 3,315 & 3,660 & 1,912 & 1,115 \\
\hline 59,390 & 75,526 & 80,843 & 106,297 \\
\hline 148,375 & 130,630 & 123,857 & 104,692 \\
\hline 207,765 & 206,156 & 204,700 & 210,989 \\
\hline 3,200 & 3,200 & 3,200 & 3,200 \\
\hline 16,000 & 16,000 & 16,000 & 16,000 \\
\hline 129,900 & 135,879 & 139,179 & 140,920 \\
\hline 149,100 & 155,079 & 158,379 & 160,120 \\
\hline 356,865 & 361,235 & 363,079 & 371,109 \\
\hline
\end{tabular}


TABLE 2

PITTMAN PLUMBING FIXTURES \& SUPPLIES, INC.

INCOME STATEMENTS

(\$ in thousands)

Sales

Cost of Goods Sold

Gross Income

Operating Expenses

Selling, General and Administrative

Officer Salaries

Lease Expense

Bad Debts Expense

Depreciation

Operating Profit

Interest Income (Expense)

Earnings Before Interest and Taxes (EBIT)

Interest Expense

Earnings Before Taxes (EBT)

Income Taxes

Net Income

\begin{tabular}{|c|c|c|c|}
\hline 2015 & 2016 & 2017 & 2018 \\
\hline $\begin{array}{r}497,950 \\
(390,094) \\
\end{array}$ & $\begin{array}{r}519,558 \\
(411,594) \\
\end{array}$ & $\begin{array}{r}562,900 \\
(453,472) \\
\end{array}$ & $\begin{array}{r}582,860 \\
(473,457) \\
\end{array}$ \\
\hline 107,856 & 107,964 & 109,428 & 109,403 \\
\hline$(34,956)$ & $(35,933)$ & $(39,797)$ & $(41,325)$ \\
\hline$(7,220)$ & $(7,794)$ & $(8,725)$ & $(9,151)$ \\
\hline$(4,980)$ & $(5,196)$ & $(5,629)$ & $(5,846)$ \\
\hline (195) & (63) & (364) & (212) \\
\hline$(23,815)$ & $(25,980)$ & $(34,640)$ & $(37,887)$ \\
\hline 36,690 & 32,998 & 20,273 & 14,982 \\
\hline 220 & 193 & 206 & 160 \\
\hline 36,910 & 33,191 & 20,479 & 15,142 \\
\hline$(8,421)$ & $(7,737)$ & $(7,601)$ & $(7,656)$ \\
\hline 28,489 & 25,454 & 12,878 & 7,486 \\
\hline$(9,685)$ & $(8,675)$ & $(4,378)$ & $(2,545)$ \\
\hline 18,804 & 16,779 & 8,500 & 4,941 \\
\hline $\begin{array}{r}18,804 \\
(12,000)\end{array}$ & $\begin{array}{r}16,779 \\
(10,800)\end{array}$ & $\begin{array}{r}8,500 \\
(5,200)\end{array}$ & $\begin{array}{r}4,941 \\
(3,200)\end{array}$ \\
\hline 6,804 & 5,979 & 3,300 & 1,741 \\
\hline
\end{tabular}

Net Income

Dividends Paid

Addition to Retained Earnings 
TABLE 3

PITTMAN PLUMBING FIXTURES \& SUPPLIES, INC.

UCA CASH FLOW STATEMENTS

( $\$$ in thousands)

Net Sales

Change in Current Receivables

Cash from Sales

Cost of Goods Sold

Change in Inventory

Change in Accounts Payable

Cash Production Costs

\section{CASH FROM TRADING}

Selling, General and Administrative Expenses

Other Operating Expenses

Change in Prepaid Expenses

Change in Accrued Expenses

Change in Other Current Assets \& Liabilities

Cash Operating Costs

\section{CASH AFTER OPERATIONS}

Other Income (Expense)

Change in Other Liabilities

Income Tax Expense

Change in Deferred Income Taxes

Change in Income Taxes Payable

Taxes Paid \& Other Income (Expense)

\section{NET CASH AFTER OPERATIONS}

Dividends or Owners Withdrawals

Change in Dividends Payable

Interest Expense

Change in Interest Payable

Cash Financing Costs

CASH AFTER FINANCING COSTS

\begin{tabular}{|c|c|c|}
\hline 2016 & 2017 & 2018 \\
\hline $\begin{array}{r}519,558 \\
(5,493) \\
\end{array}$ & $\begin{array}{r}562,900 \\
(2,392) \\
\end{array}$ & $\begin{array}{r}582,860 \\
(6,062) \\
\end{array}$ \\
\hline 514,065 & 560,508 & 576,798 \\
\hline$(411,594)$ & $(453,472)$ & $(473,457)$ \\
\hline$(19,672)$ & $(21,310)$ & $(5,057)$ \\
\hline 11,895 & $(8,148)$ & 5,098 \\
\hline$(419,371)$ & $(482,930)$ & $(473,416)$ \\
\hline 94,694 & $\mathbf{7 7 , 5 7 8}$ & 103,382 \\
\hline$(35,933)$ & $(39,797)$ & $(41,325)$ \\
\hline$(12,990)$ & $(14,354)$ & $(14,997)$ \\
\hline 86 & (779) & 433 \\
\hline (309) & 541 & 516 \\
\hline 0 & 0 & 0 \\
\hline$(49,146)$ & $(54,389)$ & $(55,373)$ \\
\hline 45,548 & 23,189 & 48,009 \\
\hline 193 & 206 & 160 \\
\hline 0 & 0 & 0 \\
\hline$(8,675)$ & $(4,378)$ & $(2,545)$ \\
\hline 0 & 0 & 0 \\
\hline 345 & $(1,748)$ & $(797)$ \\
\hline$(8,137)$ & $(5,920)$ & $(3,182)$ \\
\hline 37,411 & 17,269 & 44,827 \\
\hline$(10,800)$ & $(5,200)$ & $(3,200)$ \\
\hline 0 & 0 & 0 \\
\hline$(7,737)$ & $(7,601)$ & $(7,656)$ \\
\hline 0 & 0 & 0 \\
\hline$(18,537)$ & $(12,801)$ & $(10,856)$ \\
\hline 18,874 & 4,468 & 33,971 \\
\hline
\end{tabular}


TABLE 3 (CONTINUED)

( $\$$ in thousands)

Current Portion Long-Term Debt

$\begin{array}{lll}2016 & 2017 & 2018\end{array}$

CASH AFTER DEBT AMORTIZATION

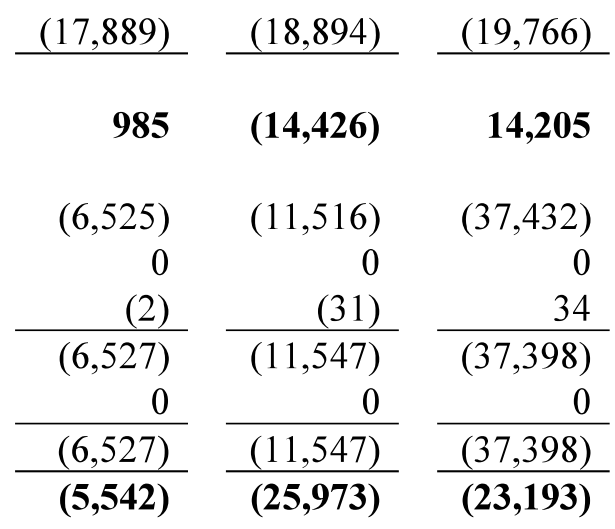

Capital Expenditures

Change in Long-Term Investments

Change in Intangibles/Other Assets

Cash Used for Plant \& Investment

Related Parties - Change in Loans from Owners

FINANCING SURPLUS/REQUIREMENT

Change in Short-Term Debt

Change in Long-Term Debt

$3,200 \quad 13,800 \quad 20,375$

$1,149 \quad 12,993 \quad 863$

Change in Contributed Capital

Other Changes in Retained Earnings

TOTAL EXTERNAL FINANCING

CHANGE IN CASH \& EQUIVALENTS

\begin{tabular}{rrrr}
0 & & 0 & 0 \\
0 & & 0 & 0 \\
\cline { 1 - 1 } & & $\mathbf{2 6 , 7 9 3 4 9}$ & $\mathbf{2 1 , 2 3 8}$ \\
\hline \hline
\end{tabular}

TABLE 4

PITTMAN PLUMBING FIXTURES \& SUPPLIES, INC. ALTERNATIVE PRESENTATION OF UCA CASH DISBURSEMENTS FOLLOWING CASH AFTER FINANCING COSTS

( $\$$ in thousands)

Cash After Financing Costs

Current Portion of Long-Term Debt

CASH AFTER DEBT AMORTIZATION

Change in Short-Term Debt

CASH AVAILABLE FOR PLANT \& INVESTMENTS

Cash Used for Plant \& Investments

Change in Long-Term Debt

\section{CASH SURPLUS/(REQUIREMENT)}

Related Parties - Change in Loans from Owners

Change in Contributed Capital

Other Changes in Retained Earnings

CHANGE IN CASH \& EQUIVALENTS

\begin{tabular}{|c|c|c|}
\hline 2016 & 2017 & 2018 \\
\hline $\begin{array}{r}18,874 \\
(17,889) \\
\end{array}$ & $\begin{array}{r}4,468 \\
(18,894) \\
\end{array}$ & $\begin{array}{r}33,971 \\
(19,766) \\
\end{array}$ \\
\hline 985 & $(14,426)$ & 14,205 \\
\hline 3,200 & 13,800 & 20,375 \\
\hline 4,185 & $(626)$ & 34,580 \\
\hline$(6,527)$ & $(11,547)$ & $(37,398)$ \\
\hline 1,149 & 12,993 & 863 \\
\hline$(1,193)$ & 820 & $(1,955)$ \\
\hline 0 & 0 & 0 \\
\hline 0 & 0 & 0 \\
\hline 0 & 0 & 0 \\
\hline$(1,193)$ & 820 & $(1,955)$ \\
\hline
\end{tabular}

